\title{
THE IMPACT OF CHARISMATIC LEADERSHIP ON TURNOVER INTENTIONS AND ORGANIZATIONAL CITIZENSHIP BEHAVIORS TOWARD JOB SATISFACTION
}

\author{
Bazawi Hiton, Syah Tantri Yanuar Rahmat*, Indradewa Rhian, Pusaka Semerdanta \\ Faculty Economics and Business, University of Esa Unggul, Indonesia \\ *E-mail: tantri.yanuar@esaunggul.ac.id
}

\begin{abstract}
Leadership plays a pivotal role in the organization. One of stlyes of leadership is charismatic leadership, of which, can improve organizational performance. The main objective of this research is to perceive how charismatic leadership can be boosted job satisfaction, reduce turnover intentions and increase organizational citizenship behaviors (OCB). To meet this objective, data collected through questionnaires distributed online to 110 employees working in Jakarta from diversed nature of organizations and was analyzed by Structural Equation Modeling (SEM) Lisrel. The results of this research indicate that charismatic leadership can be boosting job satisfaction, organizational citizenship behaviors, yet, the job satistaction and organizational citizenship behaviors are also increasing turnover intentions in the organization. This finding is fascinating since previous researches show the job satisfaction and charismatic leadership may reduce turnover intentions. To conclude, this study has several insighful and eye opener facts for the management-charismatic leadership and high degree of job satisfaction do not guarantee the employees remain in the same organization.
\end{abstract}

\section{KEY WORDS}

Charismatic leadership, job satisfaction, turnover intentions, organizational citizenship behaviors, employees, Jakarta.

Charismatic leadership has always been an interesting variable to discuss and explore. Among the researchers who had been researched, the influence of charismatic leadership are Babcock-Roberson \& Strickland, 2010; Chung et al., 2011; Vlachos et al., 2013; Zehir et al., 2014; and Lindblom et al., 2016.

Researchers in Organizational Behavior Study have been prolonged interested in exploring how employees' perceptions toward their leaders, influence the thoughts and behaviors associated with their work. The above studies showcase a significant positive linkage between charismatic leadership towards work engagement and organizational citizenship behaviors. Moreover, charismatic leadership approaches the organizational citizenship behaviors through work involvement has a significant positive impact (BabcockRoberson \& Strickland, 2010). On the other hand, self leadership skill complements the charismatic leadership; it does not replace the influence of charismatic leadership in the context of internalization and identification (Chung et al., 2011).

Zehir et al. (2014) reveal how charismatic leadership has a positive impact on ethical climate and organizational citizenship behaviors. Ethical climate is found as an unstrong mediatiton between charismatic leadership and organizational citizenship behaviors, however, this ethical climate is able to approach the interpendence amongst the dimensions of civic wisdom in organizational citizenship behavior, dimensions of sensitivity to the environment, strategic vision and articulation, sensitivity to the needs of members and the status quo.

In the retail industry, charismatic leadership also significantly influenced the job satisfaction, self-efficacy, organizational identification and turnover intentions. Employees's perception on charismatic leadership has a strong positive affection particularry to frontline employees, job satisfaction, self-efficacy, and organizational identification. Nonetheless, charismatic leadership has a strong negative impact on turnover intentions. Frontline employees remain in the same office despite getting attractive and better offers in another business (Lindblom et al., 2016). In line with Lindblom et al. (2016), the results of previous 
studies were also carried out by Vlachos et al. (2013) that charismatic leadership greatly influences employee job satisfaction, either directly or mediated by intricate values. While employees' points of view of their managers have charismatic leadership qualities, they tend to be actively involved in Corporate Social Responsibility (CSR) activities with intrinsic values. This leads to job satisfaction.

Previous studies rarely discussed specifically in the influence of charismatic leadership on job satisfaction, turnover intentions, and organizational citizenship behaviors. Previous research shows limited findings in charismatic leadership which has a direct and significant effect towards ethical climate, turnover intentions, organizational citizenship behaviors, job satisfaction, self-efficacy, self-leadership, organizational identification and work involvement. This research may distinguish from previos studies since we include charismatic leadership effects on turnover intentions and organizational citizenship behaviors that are mediated by job satisfaction.

The objectives of this research are: first, to learn how charismatic leadership influences job satisfaction; second, to find out how employee's job satisfaction affects turnover intentions; third, to find out how job satisfaction influences organizational citizenship behaviors; fourth, to find out how charismatic leadership influences turnover intentions; and fifth, to find out how charismatic leadership influenced organizational citizenship behaviors. Finally, we elaborate the findings of this research and provide some practical and theoretical implications.

\section{LITERATURE REVIEW}

Charismatic leadership theory is currently adopted Max Weber's ideas (1947, as cited in Yukl, 2010) - a sociologist from Germany defines the charisma comes from Greek literature which means gift. This charasimatic leader has an ability to do miracles or predict the future. According to Weber, charisma occurs when social crisis happens. This leader emerges with a radical vision that offers a solution to the crisis, attract followers who believe in that vision. Thus, this vision is achieved and the followers believe that this leader is an extraordinary person. Conger \& Kanungo (1987) defines charismatic leadership is an attribute stated by followers who observe certain behaviors in the leader at the organization. Charismatic leadership and other types of leadership can be studied as a dimension of leadership. Such as participatory, task or people orientations. By tracing the basis of perceived charisma behavior, the construct has dropped from its mystical epiphenomenal status to a phenomenal status that can be observed empirically (Conger \& Kanungo, 1992). Charismatic leadership behavior includes strategic vision, high quality articulation, sensitivity to the environment and the needs of the follower, personal risks taking and unconventional behavior (Conger et al. 1997). Charismatic leadership according to Robbins \& Judge (2012), is the leader, who the followers believe that he/she has extraordinary attributes of heroism with the certain actions. Choi (2006) argues that charismatic leadership consists of three components, namely envisioning, empathy and empowerment.

Job satisfaction according to Davis (1985) is a pleasant or unpleasant feeling experienced by the employees at work. Job satisfaction is a positive emotion about work. This result comes from an evaluation of each job's characteristics. The content workers increase customer satisfaction and loyalty, constructive OCB, and effective performance (Robbins \& Judge, 2012). Job satisfacton is an emotion that reinforce or does not reinforce employees, with their work and themselves. Emotions at work involve multiple aspects such as wages career development opportunities, relationships with other employees, work placements, types of work, company organizational structure, quality of supervision. Whereas self emotions related to his/her personal portray, including age, health conditions, abilities and education (Mangkunegara, 2015).

Turnover intentions are an intention or individual effort to end the employment within the organization at a certain time. Turnover is defined as the discharge of employment from the company permanently by employees (voluntarily) or by the company (Robbins \& Judge, 2012). Turnover intentions are referred to employee behavioral tendencies (voluntarily) to 
leave the organization. Previous research was found that turnover intentions were stronger caused and direct predictors of actual turnover (Jang \& George, 2012). High turnover intentions can disrupt company financial position, leads to low organizational performance, productivity, morale and disruption of services. Those lead to customer dissatisfaction (Simons \& Hinkin, 2001).

Bateman \& Organ (1983) argues that organizational citizenship behaviors include behaviors to assist colleaque, works by orders (without rejection), not complaining on additional assignments aside from normal routines, paying attention to cleanliness and tidiness of working space, talking positively with regard to the organization, to build a healthy and warmth atmosphere, and utilize organizational resources efficiently. Organizational citizenship behaviors explicitly described by Organ (1988) are individual behaviors that are discretionary, not directly or explicitly recognized by the formal system, and in aggregate promote the effective functioning of the organization. Discretion in this research is, the behavior to perform without the job description or clear directions outlined in the contract, hence it is done by the personal initiative. As a result, the punishment will not be implemented if the job negligent occurred. Podsakoff et al. (2000) specifically examined the literature on organizational citizenship behaviors and other related constructs. The research was conducted to explore the conceptual similarities and differences between the various forms of "citizenship" identified in the literature. The research also summarizes the empirical findings from both the antecedents and consequences of organizational citizenship behaviors. Furthermore, this research also identified some interesting directions for future research.

\section{HYPOTHESES DEVELOPMENT}

Job satisfaction in a company or organization does not come naturally (Lebi \& Anindita, 2018). Many factors influence employee job satisfaction, like compensation, transformational leadership, charismatic leadership, work environment, and others. Lindblom et al. (2016) conducted a study on the Finnish retail industry relating to the influence of charismatic leadership on job satisfaction, and the results of his research found that charismatic leadership has a robust impact on job satisfaction, meaning that charismatic leadership leads to job satisfaction. This research also relates to Vlachos et al. (2013), who also do research on charismatic leadership. Vlachos et al. (2013) argue that charismatic leaders impose behaviors that give meaning to employees' work. This leader also give challenges with broader targets. Once the targets are achive, it elevates the sense of job satisfaction for employees.

From the above argument, the researcher proposed the hypothesis:

H1: Charismatic leadership will positively relate to job satisfaction.

To analyze turnover intentions, the researchers focused on the relationship between turnover intentions and their predictive variables. An overview of the results of his research reveals that variables such as job satisfaction, organizational trust, managerial support, and equalities, have clear predictive roles on turnover intentions (Lee et al., 2017). In the study of Arfian \& Anindita (2017) it was found that low job satisfaction leads to enlarge turnover intentions ratio, meaning that to reduce turnover intentions, the organization must expand job satisfaction, as a result turnover intentions increased significantly. Zhang \& Feng (2011) in his research conducted in Hubei, China to 1,600 doctors showed that there might be the effect of work fatigue, especially emotional fatigue, thus the impact of job satisfaction on turnover intentions increased. This indicates that the increase of job satisfaction is expected to reduce the turnover of the intention of doctors in Hubei, China. The results of the study are also in line with the research conducted by Shu et al. (2018) which states that job satisfaction significantly affects turnover intentions in family business.

From the above argument, the researcher proposed the hypothesis:

H2: Job satisfaction will negatively relate to turnover intentions.

The relationship between job satisfaction and organizational citizenship behaviors has been investigated by many researchers and widely published. The results of testing the 
relationship between job satisfaction and organizational citizenship behaviors that were moderated by team commitment showed that the stronger of the relationship, the higher team commitment (Foote \& Tang, 2008). This research is strengthened by Mogotsi et al. (2011) who conducted a research of secondary school teachers in Botswana; the results stated that job satisfaction is a strong predictor of organizational citizenship behaviors.

From the above argument, the researcher proposed the hypothesis:

H3: Job satisfaction will positively relate to organizational citizenship behaviors.

In general, it has been suggested that turnover intentions decrease when the leaders value their members and highlight individual values and their contribution (Dixon \& Hart, 2010). For example, (Lindblom et al., 2016) assume that frontline employees prefer to be lead by charismatic retailer, thus they want to be supervised by this charismatic retailer, even if there are better alternatives., the frontline employees choose to remain in this organization. This proves that the influence of charismatic leadership is very strong towards employee intentions, meaning that charismatic leadership can reduce employee turnover intentions.

From the above argument, the researcher proposed the hypothesis:

H4: Charismatic leadership will negatively relate to turnover intentions.

Previous research conducted by Babcock-Roberson \& Strickland (2010) shows empirical support for the mediating role of work engagement in the relationship between charismatic leadership and organizational citizenship behaviors. These findings support the idea if charismatic leaders are present, employees are more active to do their job, and ultimately promote citizenship behaviors. In line with Babcock-Roberson \& Strickland (2010), Zehir et al. (2014) also examined the role of mediating ethical climate in the relationship between charismatic leadership and organizational citizenship behaviors. However, the results of his research indicate that ethical climate was found to be an unstrong mediator in the relationship between charismatic leadership and organizational citizenship behaviors. Furthermore, Zehir et al. (2014) also examined the direct relationship between charismatic leadership and organizational citizenship behaviors, the result reveal the charismatic leadership had a very strong direct effect in improving organizational citizenship behaviors.

From the above argument, the researcher proposed the hypothesis:

H5: Charismatic leadership will positively relate to organizational citizenship behaviors.

\section{METHODS OF RESEARCH}

This research was conducted in November 2018 in Jakarta using the causality research method to see the relationships between variables. The analytical tool used is Structural Equation Model (SEM) Lisrel. Therefore, the minimum samples are five times from the total number of statements analyzed according to Hair et al. (2014). The research questionnaire contained 19 statements; hence, the minimum number of samples needed was 95 respondents. In this research, the respondents are 110 employees who had been worked for more than two years. The variable of research is focused on charismatic leadership, job satisfaction, turnover intentions and organizational citizenship behaviors. The data measurement method was adopted Likert scale with one to five scale intervals.

In this study there is one exogenous variable which is charismatic leadership and three endogenous variables, which are job satisfaction, turnover intentions and organizational citizenship behaviors. Measurement of charismatic leadership variables using the dimensions of Conger et al. (1997) which consists of strategic vision and articulation, sensitivity to environment and members needs, personal risk, and unconventional behavior; of which the researcher only focus on the dimensions of strategic vision and articulation. On the other hand, job satisfaction variables that had been used is the dimensions apply DeVaney \& Chen (2003) which consist of attitude, pay, stress, job security, colleaque, company policy and support, and promotion. However, the researcher only focuses on the dimensions of attitude and colleaque. The turnover intentions variable adopts the Keaveney (1992) indicator which consists of 4 indicators. Moreover, the researcher apply Van Dyne et al dimension (1994) for the organizatioal behaviour, which consists of loyalty, obedience, and 
participation; however the researcher only highlight the dimension of loyalty. Lastly, all the measurements were consolidated in the questionnaires and tested the validity and reliability.

Validity test had done by Confirmatory Factor Analysis, with the value of Kaiser-MeyerOlkin Measure of Sampling (KMO) and Measures of Sampling Adequacy (MSA). In this test, the value obtained must be greater than 0.500 which means that factor analysis is sufficient to observe, and can be further processed (Doll et al., 1994). The charismatic leadership's scale consists of 7 statements (all valid); on the otherhand, the turnover intentions scale consists of 4 questions (all valid). In addition, the job satisfaction scale consists of 6 statements, which consist of 2 invalid statements, since the component matrix is more than one JS1 (0.450) and JS3 (0.579). While the scale of organizational citizenship behaviors consists of 5 statements including 1 invalid statement is OCB4 (0.501). Since the Cronbach Alpha reliability test is greater than $>0.5$; it means the data is reliable (Sugiyono, 2012), thus these indicators of all variables are trusted data in this research. The next step, the researcher processed the data with Structural Equation Modeling (SEM) analysis method. SEM is able to explain the relationship of complex variables with their direct or indirect effects on one or several variables towards other variables (Hair et al., 2014).

\section{RESULTS AND DISCUSSION}

In using SEM analysis, we also have to see compatibility of the whole model (goodness of fit). Based on that analysis, it is found that almost all results are compatible in good fit. This indicated that good fit is the result of compatibility in accordance with the values referred, while marginal fit is the result of compatibility under the values referred. Several tests were done in order to show sufficient compatibility, they were Chi-Square, RMSEA, ECVI, AIC, and CAIC, Fit Index and goodness of fit. There is a marginal fit result for Critical $\mathrm{N}$. From the abovementioned results, it can be concluded that goodness of fit model is qualified

Table 1 - Hypotheses testing results

\begin{tabular}{|c|l|c|c|}
\hline Hypotheses & \multicolumn{1}{|c|}{ Hypotheses statement } & T-Value & Detail \\
\hline H1 & $\begin{array}{l}\text { Charismatic leadership will positively relate to job } \\
\text { satisfaction }\end{array}$ & 3,12 & $\begin{array}{c}\text { Data support the } \\
\text { hypothesis }\end{array}$ \\
\hline H2 & Job satisfaction will negatively relate to turnover intentions & 1,08 & $\begin{array}{c}\text { Data not support the } \\
\text { hypothesis }\end{array}$ \\
\hline H3 & $\begin{array}{l}\text { Job satisfaction will positively relate to organizational } \\
\text { citizenship behaviors }\end{array}$ & 2,50 & $\begin{array}{c}\text { Data support the } \\
\text { hypothesis }\end{array}$ \\
\hline H4 & $\begin{array}{l}\text { Charismatic leadership will negatively relate to turnover } \\
\text { intentions }\end{array}$ & 0,71 & $\begin{array}{c}\text { Data not support the } \\
\text { hypothesis }\end{array}$ \\
\hline H5 & $\begin{array}{l}\text { Charismatic leadership will positively relate to } \\
\text { organizational citizenship behaviors }\end{array}$ & 2,61 & $\begin{array}{c}\text { Data support the } \\
\text { hypothesis }\end{array}$ \\
\hline
\end{tabular}

The results of testing the first hypothesis $(\mathrm{H} 1)$ found that the data supports the hypothesis with a t-value of 3.12. It shows the charismatic leadership can increase job satisfaction. The results of this study are in line with research conducted by Lindblom et al. (2016); of which the charismatic leadership has a strong positive impact on job satisfaction. In addition, the results of this research also reinforce previous research conducted by Vlachos et al. (2013) that reveal the charismatic leadership is able to provide employees with strategic goals and inspiring visions. Therefore, the results of its achievement lead to higher job satisfaction.

The results of testing the second hypothesis $(\mathrm{H} 2)$ found that the data did not support the hypothesis with a t-value of 1.08, which is high level of job satisfaction can reduce turnover intentions. The results of this study are different from previous studies conducted by Y. Zhang \& Feng (2011); Arfian \& Anindita (2017); Lee et al. (2017); Shu et al. (2018) which mentions the effect of job satisfaction on turnover intentions. The difference findings on this reseaarch may be the researcher did not taking the overall dimensions of job satisfaction DeVaney \& Chen (2003). Another finding is, the employees may feel high level of job 
satisfaction, but because the salary is quite low, he or she may consider an alternative offer with a competitive salary. In addition, it is likely that employees with high level job satisfaction but without promotion, he or she may consider to work at another companies that give them higher promotions and wages.

The results of testing the third hypothesis $(\mathrm{H} 3)$ found that the data supports the hypothesis with a t-value of 2.50, which is high level job satisfaction can improve organizational citizenship behaviors. The results of this study are in line with the research conducted by Basirudin et al. (2016); Foote \& Tang (2008); Ertürk et al. (2004) that job satisfaction significantly increases organizational citizenship behaviors.

The results of testing the fourth hypothesis $(\mathrm{H} 4)$ found that the data did not support the hypothesis with a t-value of 0.71 , which was charismatic leadership can reduce turnover intentions. The results of this study are different from previous studies conducted by Lindblom et al. (2016); Wu \& Wang (2012) which states that charismatic leadership has a significant negative impact on turnover intentions. These results are directly proportional to the employees studied feeling comfortable working under charismatic leaders, thus, even though there are better alternatives, the employee will choose to stay. Whereas, the results of this study differ from previous studies since the researcher did not take all dimensions of charismatic leadership (Conger et al., 1997).

The results of testing the fifth hypothesis (H5) found that the data supported the hypothesis with a t-value of 2.61 , that charismatic leadership can improve organizational citizenship behaviors. The results of this study are in line with the research conducted by Babcock-Roberson \& Strickland (2010); Zehir et al. (2014) that the charismatic leadership was significantly positive on organizational citizenship behaviors. When a leader shows sensitivity to the needs and feelings of organizational members, sets strategic and inspire to achieve organizational goals, employees tend to show citizenship behaviors. In addition, when charismatic leaders build positive and mutual relationships with employees, employees will voluntarily aspire each other.

\section{CONCLUSION}

This study examined the influence of charismatic leadership on job satisfaction, turnover intentions and organizational citizenship behaviors. This study uses the analysis of Structural Equation Model (SEM) Lisrel. The results that can be concluded from this study are: (i) charismatic leadership positively influences employee job satisfaction, which means that charismatic leadership improves employee job satisfaction (the first hypothesis is supported); (ii) job satisfaction negatively affects turnover intentions significantly. High job satisfaction reduces turnover intentions (second hypothesis is not supported); (iii) job satisfaction positively influences the organizational citizenship behaviors. High job satisfaction will enhance organizational citizenship behaviors (third hypothesis supported); (iv) charismatic leadership significantly affects turnover intentions, which means charismatic leadership reduces turnover intentions (fourth hypothesis is not supported); and (v) charismatic leadership positively influences organizational citizenship behaviors. Lastly, charismatic leadership enhances organizational citizenship behavior (the fifth hypothesis is supported).

This study has several limitations that can be considered for further research. This study only carried out in Jakarta from varied nature of companies and respondents who have two years work experiences. This study uses a questionnaire as a measurement tool with the aim of saving time and effort. Therefore, there is a possibility that the respondent did not fill in the questionnaire with the actual answer or only filled in based on the ideal conditions expected and not the conditions that were happening. This can cause the measurements do not describe the actual variables. In addition, the limitations of the variables examined in this study only discuss charismatic leadership with one dimension from five that must be researched, Moreover, the job satisfaction used only two dimensions from seven dimensions that must be examined. Lastly turnover intentions and organizational citizenship behaviors only applied one dimension of three dimensions that should examined. 
This research is still very limited, because it has only done in Jakarta and the respondents are the employees who have two years experience. This research is also limited to examining the influence of charismatic leadership on job satisfaction, turnover intentions and organizational citizenship behaviors. Therefore, the researcher suggests the development of further research by adding those three variables. There are many other variables, besides charismatic leadership factors that can be maximazing those variables. In addition, future research is suggested to use all existing dimensions in each variable, to examine one type of company such as goods, services or manufacturing companies. Another suggestion is the location of the research is carried out in various cities, therefore the research outcome can be more optimal, objective and in accordance with the hypothesis that was stated from the beginning.

\section{REFERENCES}

1. Arfian, M. H., \& Anindita, R. (2017). Determinants of Turnover intentions in Information Technology Workers. International Journal of Economics, Commerce and Management, United Kingdom, V(4), 584-598.

2. Babcock-Roberson, M. E., \& Strickland, O. J. (2010). The Relationship Between Charismatic Leadership, Work Engagement, and Organizational Citizenship Behaviors. The Journal of Psychology, 144(3), 313-326.

3. Basirudin, N. B., Basiruddin, R., Mokhber, M., Rasid, S. Z. A., \& Zamil, N. A. M. (2016). Organizational Citizenship Behaviour in Public Sector: Does Job Satisfaction Play a Role. International Journal of Economics and Financial Issues, 6, 376-381.

4. Bateman, T. S., \& Organ, D. W. (1983). Job Satisfaction and Good Soldier: The Relation Between Affect and Employee Citizenship. Academy of Management Journal, 26, 587595.

5. Choi, J. (2006). A Motivational Theory of Charismatic Leadership: Envisioning, Empathy, and Empowerment. Journal of Leadership \& Organizational Studies, 13(1), 24-43.

6. Chung, A., Chen, I., Lee, A. Y., Chen, H. C., \& Lin, Y. (2011). Charismatic leadership and self-leadership or supplementation in the contexts, 24(3), 299-313.

7. Conger, J. A., \& Kanungo, R. N. (1987). Toward a Behavioral Theory of Charismatic Leadership in Organizational Settings. Academy of Management Review, 12(4).

8. Conger, J. A., \& Kanungo, R. N. (1992). Perceived Behavioural Attributes of Charismatic Leadership. Canadian Journal of Behavioural Science, 24(1), 86-102.

9. Conger, J. A., Kanungo, R. N., Menon, Sanjay, T., \& Mathur, P. (1997). Measuring Charisma: Dimensionality and Validity of the Conger-Kanungo Scale of Charismatic Leadership. Revue Canadienne Des Sciences de l'Administration, 290.

10. Davis, K. (1985). Human Behavior at Work: Organizational Behavior. New Delhi : Tata McGraw-Hill Publishing Company.

11. DeVaney, S. A., \& Chen, Z. (Sandy). (2003). Job Satisfaction of Recent Graduates in Financial Services. U.S. Bureau of Labor Statistics.

12. Dixon, M. L., \& Hart, L. K. (2010). The Impact of Path-Goal Leadership Styles on Work Group Effectiveness and Turnover Intention. Journal of Managerial Issues, 22, 52-69.

13. Doll, W. J., Xia, W., \& Torkzadeh, G. (1994). A Conformatory Factor Analysis of the enduser Computing Satisfaction Instrument. MIS Quarterly, 18(4), 453-461.

14. Ertürk, A., Yılmaz, C., \& Ceylan, A. (2004). Promoting Organizational Citizenship Behaviors: Relative Effects of Job Satisfaction, Organizational Commitment, and Perceived Managerial Fairness. METU Studies in Development, 31, 189-210.

15. Foote, D. A., \& Tang, T. L. (2008). Job Satisfaction and Organizational Citizenship Behavior (OCB) Does Team Commitment Make a Difference in Self-Directed Teams? Management Decision, 46(6), 933-947.

16. Hair, J. F., Black, W. C., Babin, B. J., \& Anderson, R. E. (2014). Multivariate Data Analysis Seventh Edition, US: Pearson Education Limited.

17. Jang, J., \& George, R. T. (2012). Understanding the Influence of Polychronicity on Job Satisfaction and Turnover Intention: A Study of Non-Supervisory Hotel Employees. 
International Journal of Hospitality Management, 31(2), 588-595.

18. Keaveney, S. M. (1992). An Empirical Investigation of Dysfunctional Organizational Turnover Among Chain and Non-Chain Retail Store Buyers. Journal of Retailing, 68, 145.

19. Lebi, R. F., \& Anindita, R. (2018). The Analysis of the Effect of Transformational Leadership and Organizational Culture on Job Satisfaction and Performance. International Advanced Research Journal in Science, Engineering and Technology, 5(10), 1-10.

20. Lee, X., Yang, B., \& Li, W. (2017). The Influence Factors of Job Satisfaction and its Relationship with Turnover Intention: Taking Early-Career Employees as an Example. Anales de Psicología, 33(2013), 697-707.

21. Lindblom, A., Kajalo, S., \& Mitronen, L. (2016). Does a Retailer's Charisma Matter? A Study of Frontline Employee Perceptions of Charisma in the Retail Setting. Journal of Services Marketing, 3(June 2015), 266-276.

22. Mangkunegara, A. A. A. P. (2015). Manajemen Sumber Daya Manusia Perusahaan Bandung: Remaja Rosdakarya.

23. Mogotsi, I. C., Boon, J. A., \& Fletcher, L. (2011). Modelling the Relationships between Knowledge Sharing, Organisational Citizenship, Job Satisfaction and Organisational Commitment among School Teachers in Botswana. Afr. J. Lib, Arch. \& Inf.Sc., 21(1), 4158.

24. Organ, D. W. (1988). Organizational Citizenship Behavior: The Good Soldier Syndrome. In Lexington, MA: Lexington Books.

25. Podsakoff, P. M., Mackenzie, S. B., Paine, J. B., \& Bachrach, D. G. (2000). Organizational Citizenship Behaviors: A Critical Review of the Theoretical and Future Research. Journal of Management, 26(3), 513-563.

26. Robbins, S. P., \& Judge, T. A. (2012). Organizational Behavior 15th ed. New Jersey: Pearson Education, Inc.

27. Robbins, S. P., \& Judge, T.A. (2015). Organizational Behavior 16th edition. New Jersey : Pearson Education, Inc.

28. Shu, X., Gong, Y., Xiong, J., \& Hu, X. (2018). Job Satisfaction, Turnover Intention and Work Performance in Chinese Family Enterprises. Management International, 84-95.

29. Simons, T., \& Hinkin, T. (2001). The Effect of Employee Turnover on Hotel Profits: A Test Across Multiple Hotels. Cornell Hotel and Restaurant Administration, 42(4), 65-69.

30. Sugiyono. (2012). Metode Penelitian Kuantitatif, Kualitatif, dan R\&D. Bandung: Alfabeta.

31. Van Dyne, L., Graham, J. W., \& Dienesch, R. M. (1994). Organizational Citizenship Behavior: Construct redefinition, Measurement, and Validation. Academy of Management Journal, 37, 765-802.

32. Vlachos, P. A., Panagopoulos, N. G., \& Rapp, A. A. (2013). Feeling Good by Doing Good: Employee CSR-Induced Attributions, Job Satisfaction, and the Role of Charismatic Leadership. Journal of Business Ethics, 118, 577-588.

33. Wu, M., \& Wang, J. (2012). Developing a Charismatic Leadership Model for Chinese Organizations: the Mediating Role of Loyalty to Supervisors. The International Journal of Human Resource Management, 23(19), 4084.

34. Yukl, G. (2010). Leadership in Organizations, seventh edition. New Jersey: Pearson Education, Inc.

35. Zehir, C., Müceldili, B., Altindag, E., S,Ehitog $\ l$, Y., \& Zehir, S. (2014). Charismatic Leadership and Organizational Citizenship Behavior: The Mediating Role of Ethical Climate. Social Behavior and Personality, 42(8), 1365-1376.

36. Zhang, Y., \& Feng, X. (2011). The Relationship Between Job Satisfaction, Burnout, and Turnover Intention Among Physicians from Urban State-Owned Medical Institutions in Hubei, China: a Cross-Sectional Study. BMC Health Services Research, 11(1), 235. 